\title{
OS SONHOS E OS DIAS. XAMANISMO NO MÉXICO ATUAL
}

Miguel A. Bartolomé

Alicia M. Barabas

Este ensaio procura conciliar três temas que podem ser teoricamente diferenciados, sendo contudo interrelacionados com frequência nas práticas de um grupo de especialistas rituais do México atual. O xamanismo como mediação com o extra-humano, o nagualismo enquanto capacidade de transformação e a viagem onírica como instrumento para vincular duas ou mais realidades são capacidades que podem coincidir ou não em um mesmo indivíduo, mas que constituem noções culturais vinculadas em uma mesma esfera conceitual. O xamanismo não é equivalente ao nagualismo, mas ambos supõem - como veremos - uma matriz similar de significados culturalmente definidos. Devemos destacar inclusive que falar do México como âmbito etnológico destes temas nos coloca diante de um problema de definição cultural significativo: nem todo o atual território mexicano foi espaço de desenvolvimento da tradição civilizatória mesoamericana, que se estendeu em direção ao sul das fronteiras estatais, chegando até a chamada área intermediária do istmo centroamericano.

O norte do México e, em especial, o noroeste foram e continuam sendo o território de culturas agrícolas sedentárias e caçadoras semissedentárias, vinculadas à tradição dos chamados "índios Pueblo" do sudoeste dos EUA, ao mesmo tempo bastante influenciadas por suas relações com a Mesoamérica. No entanto, este conjunto de culturas conseguiu conservar suas singularidades até os dias de hoje, dentre elas - e adiantamos o resultado do registro etnográfico ${ }^{1}$ - a de não contar com uma noção cultural equivalente ao estruturado nagualismo mesoamericano, apesar de também terem sonhos, xamãs e, eventualmente, algumas pessoas poderem se transformar em animais. Mas o enfoque principal de nossa pesquisa recai sobre o âmbito majoritário mesoamericano.

Temas como o xamanismo foram amplamente visitados pela reflexão antropológica, ainda que nosso âmbito não tenha sido tão privilegiado por estudos a este respeito. Como veremos, tal como em outras latitudes, seja 
na Ásia, na África ou na América do Sul, muitas pesquisas locais centraram-se na figura do xamã enquanto indivíduo de especial carisma e que pode utilizar substâncias psicoativas. Outros especularam sobre as origens culturais da instituição, considerando-a evidência de um substrato arcaico de caçadores coletores. Tampouco esteve ausente a crítica à própria noção de xamanismo. Apesar da diversidade de enfoques, certa constante consiste na importância atribuída ao especialista em si (ver, por exemplo, a antologia de G. Seaman \& Jane Day 1994).

Contudo, nosso interesse se orienta antes para seu papel social contemporâneo, na medida em que é depositário de um conjunto de saberes e práticas que conhece e desempenha, mas que constituem construções ideológicas das sociedades das quais fazem parte. Sem um contexto cultural específico que lhes outorgue sentido, as ações xamânicas transcorreriam em uma orfandade simbólica que as privaria da eficácia que as torna plausíveis em seu âmbito comunal. Para além de suas individualidades, eles são os atores de um roteiro que integra o texto de cada cultura. Neste ensaio, trataremos então de nos aproximar de algumas das chaves textuais com as quais as culturas locais constroem suas "lógicas xamânicas". Uma delas é a transcendência crucial do sonho como canal de comunicação entre realidades alternativas.

\section{Uma introdução ao sonhar}

O título geral sob o qual aparece esta obra e que também alude a um dos aspectos centrais de seu conteúdo é uma paráfrase do ensaio do filósofo grego Hesíodo, Los trabajos y los días, escrito há cerca de 2.700 anos. Este autor propunha que os seres humanos estão obrigados (ou condenados) ao trabalho como parte do destino de nossa espécie. Do mesmo modo, sonhar é parte de nosso destino existencial, condicionado pela incessante atividade do pensamento. Todas as culturas, incluindo a atual tradição científica mundial, tentaram encontrar explicações e sentidos para estas ideações que parecem alheias à vontade daquele que as gera. Contudo, nosso trabalho não pretende traduzir seus sentidos e simbolizações em termos de tradições culturais diferentes daquelas nos quais foram registrados. Somos orientados por uma perspectiva emic que implica, do ponto de vista metodológico, renunciar ao reducionismo que suporia subsumir as diferentes experiências oníricas das culturas indígenas mexicanas em categorias que lhes são alheias. Não é que neguemos as possibilidades deste tipo de análise, e sim que agora nos interessa o ponto de vista dos protagonistas, o que possibilitará, inclusive, outro tipo de estudo. 
A investigação dos sonhos em culturas distintas às do observador integra a mais antiga tradição antropológica, ainda que a etnologia mexicana — com algumas exceções - não tenha se ocupado muito do tema. Jacques Galinier (2009:93), em seu ensaio sobre o sonho otomí, nos lembra que o renomado especialista dos Maias, Robert Laughlin, assinalava, em 1976, que tudo o que sabia sobre o sonho entre os indígenas mesoamericanos poderia caber em três páginas. Houve alguma evolução, mesmo que ainda reste muito por aprender. ${ }^{2}$ Neste ensaio, não pretendemos desenvolver a história dos estudos a este respeito, e sim destacar alguns autores e temas - geográfica e culturalmente distantes - cujos aportes teóricos são particularmente interessantes para que se entenda melhor o resultado das pesquisas em nosso contexto. Talvez uma das mais sugestivas obras pioneiras tenha sido desenvolvida por Baldwin Spencer e Francis Gillen (1899) entre os Araunta da Austrália Central, que o advertiram sobre a existência de uma noção cultural constituída pela concepção de um âmbito de residência dos ancestrais dos seres humanos chamado Alchera, espaço que se vinculava com o tempo das origens, no qual transcorriam os mitos, e que era qualificado por eles também como "tempo do sonho" (dreamtime).

Muitos cientistas sociais aprofundaram esta concepção que vincula o mundo dos sonhos com o tempo das origens, configurando um espaço-tempo sacralizado, entre eles, Emile Durkheim (1912) e Lucien Lévy-Bruhl (1922), dando lugar a sofisticadas reflexões antropológicas. Algumas das mais recentes, como a do australiano Colin Dean (1996), postulam que o dreamtime constitui uma espécie de partitura sagrada que proporciona o conhecimento para as normas da vida, e que no Alchera residem não somente as essências vitais dos antepassados, mas também das plantas e dos animais primevos. De fato, a atual página web dos nativos australianos reivindica o dreamtime como o âmbito no qual residem as entidades anímicas de ancestrais, animais totêmicos e plantas, mas também como o espaço-tempo do qual provêm seus desenhos e modelos para as criações artísticas. Trata-se, portanto, de uma das primeiras e mais claras definições de um mundo alternativo, um espaço-tempo derivado do tempo das origens e ao qual se acede através da experiência onírica humana.

Nada mais distante da Austrália do que a complexa tradição civilizatória mesoamericana, com a qual não possui qualquer vínculo histórico ou cultural. No entanto, acreditamos poder propor que o Alchera é uma concepção que tem seus correlatos locais, na medida em que também existem espaços-tempo originários - ou metatemporais e multilocais - que são simultaneamente passados, presentes e futuros, além de ubíquos, e aos quais se acede mediante o sonho. Este ensaio não pretende contribuir para a história das religiões 
ou do pensamento, razão pela qual não nos preocupa vincular o sonho com determinados tipos de culturas, mas antes caracterizá-lo como instrumento ontológico, na medida em que contribui para o conhecimento do que uma sociedade considera como a estrutura de sua realidade. Neste caso, nos interessa basicamente a atividade onírica dos conhecedores, daqueles que a utilizam como ferramenta para ter acesso à natureza profunda das coisas, que a vigília não revela ou dificulta a compreensão. Esses conhecedores são precisamente os xamãs, os homens e as mulheres que recorrem a este transe cotidiano que é o sonho para realizar uma mediação entre sua coletividade e o mundo das entidades anímicas, povoado de penumbras e perigos, mas não menos real e atuante que a vida cotidiana.

Em sua obra clássica, Mircea Eliade (1960) propôs definir o xamanismo de forma estrita mediante o manejo das técnicas do êxtase, que conduzem a estados de transe (como o voo mágico), nos quais o indivíduo ingressa em outros níveis da consciência que lhe permitem a comunicação com as divindades. ${ }^{3}$ É claro que, ainda que êxtase e transe sejam muitas vezes utilizados como sinônimos, não o são, já que o primeiro supõe imobilidade e contemplação e o segundo alude à mobilidade e se evidencia em manifestações físicas. No entanto, ambos têm lugar na vigília e fazem alusão a uma intensa comunicação com as entidades, estabelecida em um tempo-espaço Outro. Cabe apontar que, no México, também encontramos evidências de práticas de possessão, que seriam aquelas nas quais indivíduos ou coletividades são tomados por entidades que se incorporam neles e que manifestam suas vontades por meio dos possessos ${ }^{4}$ (F. Laplantine 1977).

Nossa posição, coincidente com a de outros autores, é que todo transe, seja induzido por sugestão, ingestão de psicotrópicos, álcool, cantos ou danças, é geralmente vivido como um sonho em seu sentido mais amplo. ${ }^{5}$ Como uma aproximação de uma realidade alternativa na qual a pessoa, o viajante onírico, encontrará algum tipo de resposta para algum tipo de pergunta. A casuística mexicana nos permite destacar que o sonho é, na atualidade, o instrumento fundamental da prática xamânica; ele nos induz a tentar contribuir para a reflexão antropológica sobre o tema a partir da nossa informação etnográfica concreta.

Partamos de uma observação genérica. Parecem-nos apressadas as propostas que trataram ou tratam de encontrar simbolismos compartilhados por toda a humanidade na atividade onírica, em especial aquelas provenientes de uma psicologia órfã de contextos culturais. Acreditamos que os símbolos que aludem a cognições, estas sim, podendo ser universais, somente encontram seu sentido dentro dos sistemas culturais nos quais foram elaborados, por exemplo, a percepção da dualidade (dia-noite, homem-mulher, esquerda-direita etc.) é, 
sem dúvida, universal, mas as simbolizações que a expressam podem recorrer a múltiplas metáforas. Isto não implica que serão inacessíveis àquele que interroga a cultura, e sim que ele deve contar com o relato dos sonhadores e os significados que estes lhe atribuem para ter acesso à sua estrutura de sentidos. Ou seja, nos movemos no mundo das narrações, ainda que a lógica textual dos sonhos não nos remeta necessariamente à lógica dos mitos - também narrações - de uma mesma cultura. As supostas regras de transformação que lhes seriam comuns, inicialmente propostas por Lévi-Strauss (1986:174), dependeriam da existência de um não demonstrado pensamento mítico ou "selvagem", aparentemente comum à geração de ambos.

Este é o mesmo argumento retomado e proposto por Philippe Descola, ao observar que mitos e sonhos derivam de processos mentais similares, motivo pelo qual a interpretação dos sonhos conjugaria códigos e regras similares às interpretações dos mitos (1989:439). Talvez, em algum momento, os mitos tenham sido sonhados, mas os séculos elaboraram seus relatos e poliram suas imagens; em troca, os sonhos podem ocorrer séculos depois do nascimento dos mitos, e de as condições do sonhador e de sua sociedade terem mudado sensivelmente. Os símbolos tampouco são imutáveis ou essenciais e, como outros aspectos do fazer humano, vão refletindo o momento cronológico do ser-no-mundo de seus criadores, que expressa a historicidade de seu pensamento. Tal como propõe Gemma Orobitg (2004), o estudo dos sonhos constitui-se em uma aproximação das teorias indígenas do conhecimento. E, tal como ocorre com todas as cognições humanas, vão mudando quando muda a realidade a que se referem, ainda que não possam atuar com base no mesmo (ou similar) código simbólico.

Desde a venerável obra de Edward Tylor (1981 [1871]), o sonho foi proposto como o fundamento da noção de alma, enquanto componente vital do corpo que pode se desprender deste ao dormir e ao morrer, constituindo uma das bases de sua teoria animista da religião. Emile Durkheim (1968 [1912]), por sua vez, questionou esta perspectiva, destacando suas inconsistências, já que nem todos os sonhos possuiriam as mesmas características ou as mesmas explicações, nem representariam necessariamente viagens das almas. Enquanto fato social, a religião não poderia depender da soma das "representações alucinatórias" individuais (1968:71), mas antes o próprio sonho - e seus sentidos - dependeria da presença de um sistema de crenças preexistente derivado das representações coletivas da sociedade.

O próprio Lucien Lévy-Bruhl, cuja questionável obra possui reflexões que podem ser resgatadas, assinalou que, nas sociedades chamadas "primitivas", o sonho não somente era considerado certo, mas também, em algumas ocasiões, a ele era outorgada mais credibilidade que aos estados de vigília. 
Uma contribuição deste autor foi a de destacar a afetividade enquanto categoria de entendimento própria de todas as culturas e, neste sentido, o sonho é um estado de consciência de alto valor afetivo, uma experiência emocional intensa, cuja própria afetividade é outorgada pela realidade (1972 [1927]). O relato dos sonhos iniciáticos xamânicos pode ser acompanhado por soluços e um estado emotivo bastante intenso, uma vez que o sonhador fica profundamente ligado à experiência afetiva que lhe fora revelada em sonhos com maior profundidade que outras experiências existenciais (M. Bartolomé 1991 [1977]).

Seguindo a tradição social francesa, em sua tentativa de constituir uma sociologia do sonho, Roger Bastide (2001 [1972]) propôs duas premissas significativas: a) nas sociedades em que sua veracidade é aceita, o sonho sempre cumpre uma função social, ainda que esta possa ser variável; e b) o tipo de sonho depende da densidade social do meio; as tendências e os simbolismos oníricos serão mais reduzidos em uma aldeia do que em uma cidade. Ou seja, nos encontramos diante de um fato social eventualmente mensurável de acordo com a proximidade física e a cultura compartilhada com seus protagonistas.

Em épocas mais recentes e sem pretender nomear todos os autores, a antologia coordenada por Bárbara Tedlock (1987) trata de conjugar enfoques psicológicos e antropológicos no estudo dos sonhos em sociedades nativas, descartando desde o início as precoces e etnocêntricas caracterizações da "mentalidade primitiva". Para muitas, se não todas as culturas, incluindo a ocidental, até a época do irredutível dualismo cartesiano entre "espírito" e "matéria", o sonho foi e é considerado um estado liminar que vincula dois mundos, nenhum dos quais tendo o status ontológico de constituir a realidade absoluta. Podem ser metáforas da vida, imagens do futuro, aprendizagens do passado, corredores anímicos que conectam distintos espaços e tempos, mas nunca somente meras fabulações.

De fato, alguns antropólogos recorreram à narrativa de seus próprios sonhos, transcorridos durante as pesquisas de campo, na tentativa de ajudar e ajudar-se a compreender a dinâmica intelectual e emotiva derivada da interação cultural na qual estavam envolvidos (B. Tedlock 1991). Sem chegar a estes extremos, um tanto pós-modernos, fica claro que nossa aproximação dos sonhos xamânicos pretende estar livre tanto dos reducionismos típicos do século XIX como dos preconceitos de um racionalismo precário que trata de traduzi-los em termos que lhes são alheios. Trata-se de estudar uma capacidade própria de toda a espécie humana que, neste caso, é exercida com uma finalidade específica por um grupo de especialistas, que trata de vincular as distintas esferas do que cada cultura entende como sua realidade. 


\section{Sonhar na Mesoamérica}

Sendo assim, se a informação etnográfica em relação aos sonhos dos indígenas no México atual era, até o momento, escassa, o registro etno-histórico sobre as antigas sociedades pré-hispânicas na época da invasão europeia não é tampouco abundante, ainda que significativo. Desde os primeiros cronistas, como Fray Bernardino de Sahagún, enfatiza-se a importância que os Naua do Altiplano Central atribuíam ao sonho, já que se narra que no Calmecac, escola de sacerdotes e dirigentes lhes

[...] ensinavam a astrologia indígena e as interpretações dos sonhos e a contagem dos anos (1977, T.I.:307 [circa 1550]) [...] Os leitores dos destinos (tonalpouhque) interpretavam os sonhos. Viam-nos no livro dos destinos e ordenavam a forma como devia ser feita a oferenda e queimavam a oferenda. E a oferenda era papel, copal, um tipo de látex chamado hule (A. López Austin 1969:103).

Estas poucas alusões nos falam mais da interpretação dos sonhos que dos sonhos em si e do modo como eram concebidos. Meio século mais tarde, o sacerdote e cronista Fray Diego de Durán (1984, Vol. I:132) informa que, entre os antigos Naua, a importância dos sonhos era tal que a fundação de Tenochtitlan, no sítio da águia e do cacto nopal, deveu-se à revelação onírica que a própria divindade tribal Huitzilopochtli proporcionou a um dos líderes sacerdotais da peregrinação asteca. Este autor, ao interrogar um ancião a respeito da razão pela qual tinha uma pintura da divindade dos agaves, obteve a seguinte resposta:

[...] uma das autoridades e déspotas de sua antiga lei que via um agave com rosto e mãos tinha sonhado e que, admirado com tal sonho, publicou que o deus dos agaves tinha aparecido para ele e fazia com que se pintasse como no sonho e o adorasse, inventando cerimônias e ritos para ele, adorando-o como a um deus... E, ao se acusar esta gente que acredita em sonhos, quando se confessam, saibam os padres confessores de índios que os tomavam antigamente como revelações divinas...

Pesquisas maiores e mais detalhadas sobre o tema proporcionariam, com certeza, muito mais material a este respeito, mas o que se expôs até agora é suficiente para dar conta da importância da vida onírica na sociedade pré-hispânica, enquanto instrumento de comunicação com as divindades. ${ }^{6}$ Mas talvez esta tarefa já tenha sido realizada, como se depreenderia da admirável síntese realizada por nosso amigo e colega Alfredo López Austin 
cuja indubitável erudição sobre a civilização mesoamericana o leva a propor que (1990:101):

[...] Também se acreditava e se acredita na possibilidade dos homens de passarem de um mundo a outro. Não somente os deuses cruzam. Os homens podem ir em sonhos, pela ingestão de fungos psicotrópicos, por êxtase, transportados pelos deuses ou caídos por acidente nos espaços de comunicação (grifos nossos). Os antigos Naua, por exemplo, acreditavam ver os deuses em outro tempo-espaço durante o sonho e em sua visão encontravam a resposta para os acontecimentos futuros. Ao regressarem, a recordação não era tão clara, pois a passagem alterava as imagens. Era preciso, então, consultar os sacerdotes que liam os temicámatl, ou livros dos sonhos, dos quais apenas restam vestígios.

Não somente no Altiplano se desenvolveu uma ideologia social no interior da qual os sonhos eram parte importante da comunicação com o mundo alternativo. Também existem evidências de sua importância em outras culturas, como no caso dos Zapotecos de Oaxaca, para os quais Pitáoxicala era considerado a divindade que regia os sonhos (T. Smith 2001:127). Mas deixemos o passado, ainda que saibamos que permite jogar alguma luz sobre o presente. Das distintas e mais recentes monografias etnográficas surgem algumas constantes que permitem, se não elaborar uma teoria dos sonhos, ao menos registrar algumas regularidades nas concepções sobre eles. Em primeiro lugar, é evidente que existe uma distinção definida entre o sonho e a vigilía; o sonhador distingue claramente entre os dois estados. Se não fosse assim, não existiriam termos para denominar o sonho e também para classificá-los. Isto exclui aquelas teorizações precárias que apresentavam os indígenas como uma espécie de psicóticos que não saberiam distinguir entre a cotidianidade e os sonhos. A distinção é bem conhecida, mas isto não quer dizer que aos sonhos seja outorgada menos realidade que à vigília, e sim que constituem o acesso a outra dimensão da realidade, um complemento da percepção humana que sua cultura define como o existente.

Assim, para os Maias lacandões de Chiapas, as pessoas, ou melhor dizendo, suas entidades anímicas, "pensam" e "veem" quando dormem, porque sonhar, wayak, é "ver", irik, durante o sono (M. Marion 1996:83). Segundo Jacques Galinier (2009:97), os Otomis não distinguem as experiências do dormir e do sonhar, que são englobadas no termo áhá que, por sua vez, serve para designar a morte, táte, mas entendida como "grande vida". María del Carmen Castillo (2010), por sua vez, assinala que entre os Ayuuk (Mixes) de Oaxaca não somente existe um termo para sonhar, kumä'ny, mas também os distintos tipos de sonhos são objeto de uma vasta tipologia. 
Fica claro, então, que há uma noção de sonho diferente da de vigília e que a distinção é de qualidade e não de realidade. Por outro lado, na Mesoamérica e, talvez de modo similar ao que propõe Juan Niño Vargas (2007:305) para o grupo amazônico, ette, o sonho, representaria o tipo de existência que se registra antes do nascimento e que se restaura com a morte, o que nos eximiria de falar em "supra" ou "inframundos" e nos possibilitaria a referência, de modo geral, a um único "mundo outro".

Todos podem sonhar, mas nem todos podem orientar seus sonhos para fins específicos, motivo pelo qual os xamãs maias tzotziles são chamados h'ilol, "aquele que vê"; todos veem, mas ele "sabe ver". O papel singular do xamã consiste precisamente em sua capacidade de transportar-se voluntariamente em sonhos ou transes entre os dois âmbitos do existente, que também poderíamos chamar o cósmico e o social, e estabelecer relações com entidades anímicas expressamente buscadas para obter a cura de um enfermo, solicitar que chova, prever o futuro, mergulhar no passado ou cumprir qualquer outra missão que mereça uma relação com o aspecto não material ou, em outras palavras, anímico da realidade.

Não se sonha somente ao dormir, já que existem vários estados de consciência próximos ao sonho, como o "sono diurno", alguns dos quais possibilitam a relação com o mundo Outro e as entidades que o povoam. Vários interlocutores indígenas nos contaram que, quando uma pessoa caminha pela montanha e o faz de maneira distraída, deixando-se levar por seus pensamentos e sem reparar muito no entorno, pode ser "raptada" pelas potências do lugar, pelas entidades donas desses espaços, cuja capacidade de ação se torna maior quando o aspecto imaterial da pessoa se encontra mais próximo do mundo extra-humano, ao diminuir seu estado de alerta consciente e perder momentaneamente suas referências espaciais e temporais. Isto fica mais evidente através da enfermidade de etiologia cultural conhecida como "susto" ou "espanto"; supõe-se que quando uma pessoa tropeça e cai, ela se "espanta" e parte de sua substância vital fica retida pela entidade que é dona do lugar, razão pela qual se requer a intervenção de um especialista ritual para recuperar esta parte do "espírito" perdido.

No entanto, nossa experiência nos permitiu observar que nem todos os tombos produzem "susto" ou "espanto": este é consequência de o indivíduo ter caído por estar distraído, absorto em seus próprios pensamentos e, por esta razão, seu aspecto imaterial não estava em alerta e se encontrava momentaneamente indefeso diante da entidade que controlava o lugar. Recordemos a citação anterior de Alfredo López Austin (1990:101), na qual se mencionam "aqueles que caíram por acidente nos espaços de comunicação". ${ }^{7}$ Em outros casos, este estado intermediário entre o sonho e a vigília é especialmente 
buscado, tal como ocorre no transe, quando o especialista obtém sinais e visões ao se concentrar. Entre os grupos indígenas do Noroeste, alguns de seus membros, por vezes, se separam da companhia humana e se dedicam a contemplar os horizontes semidesérticos durante horas, alcançando estados de consciência próximos ao "sono" diurno, que esperam que os conectem ao mundo das entidades extra-humanas, na busca de alguma resposta para seus questionamentos existenciais.

As narrações contemporâneas dos sonhos nos grupos de tradição mesoamericana nos permitem ter acesso a uma espécie de Alchera, a um "mundo outro" (como o chamou Michel Perrín, 1995), "mundo espelho", "âmbito das divindades" ou, talvez, com maior precisão descritiva, espaço-tempo das entidades extra-humanas, que é parte integral das distintas noções culturais referentes à natureza do real. É um espaço porque nele habitam os Donos dos Animais, das Montanhas, das Águas e outras entidades territoriais. Também está povoado pelas essências anímicas de humanos, plantas, animais, minerais e de todas as substâncias que integram o universo da vigília, ainda que possam ocupar distintos planos (multilocalidade). Além disso, é factível encontrar as divindades criadoras, os ancestrais e os heróis culturais dos tempos primevos, razão pela qual não se trata apenas de um espaço heterogêneo, mas representa também uma temporalidade paralela, que inclui o passado, o presente e o futuro (multitemporalidade), já que ali estão ocorrendo simultaneamente todas as temporalidades, o que possibilita a adivinhação do porvir e o conhecimento de acontecimentos passados.

Das características deste espaço-tempo se destacam as estratégias oníricas dos xamãs, ao mesmo tempo em que as narrações de tais práticas e estratégias permitem caracterizá-lo. Em certas ocasiões, ele é concebido como um supramundo e, em outras, como um inframundo e, eventualmente, como os dois simultaneamente; espaço das divindades e terra dos mortos. Não acreditamos ser possível propor nenhuma continuidade com uma única noção pré-hispânica, já que somente conhecemos com certa profundidade as concepções maias e astecas graças à pesquisa etno-histórica. ${ }^{8}$ Talvez a evangelização colonial tenha influenciado a manutenção de uma distinção entre céu e inferno, concebidos como supra e inframundo, ao mesmo tempo em que unificados como âmbito das entidades anímicas.

No entanto, não parece apressado propor uma base material para esta construção metafísica. A percepção do tempo e do espaço vincula-se sempre ao ciclo do sol, ainda que sua ausência noturna seja concebida como parte de um mesmo percurso recorrente. O mundo diurno é visível, o noturno, iluminado ou regido pela mesma entidade, somente sendo imaginável ou acessível mediante a atividade onírica. Nele habitam os componentes 
anímicos dos entes diurnos e, por esta razão, somente pode ser visitado por eles ou pelos aspectos imateriais constituintes das pessoas. Mas existe uma constante proporcionada pelo registro etnográfico. Em cada cultura específica, os sonhadores, sejam ou não xamãs ou, em outras palavras, suas entidades anímicas, transportam-se a um mundo paralelo conhecido por todos, já que o tempo-espaço do sonho não tem uma definição individual sendo uma noção compartilhada, construída pelas representações coletivas de cada sociedade.

Nas diferentes culturas, encontramos distintos matizes do espaço-tempo paralelo e é muito difícil propor uma formulação geral que inclua todas. ${ }^{9}$ No entanto, não resta dúvida de que, nas tradições indígenas do México, o sonho coexiste com o transe, ou é equivalente ao mesmo, já que os xamãs locais o utilizam para ter acesso a um espaço-tempo caracterizado com distintas representações e denominações, no qual atuam como mediadores entre sua coletividade e as entidades extra-humanas e anímicas que o habitam.

\section{O xamanismo no México}

Desde a precoce sistematização de Mircea Eliade (1960 [1951]), o conceito de xamanismo teve uma sorte desigual, passando de uma aceitação inicial acrítica a um questionamento radical de sua natureza e até mesmo de sua aceitação como categoria etnológica válida. Como todos os conceitos antropológicos, "xamã" é uma construção na qual foram levados em conta determinados elementos, entre eles, técnicas do êxtase, capacidade de transe, ingestão de psicotrópicos, voo mágico, mediação entre dois mundos, liderança ritual, papel de curador, utilização de espíritos auxiliares, controle do fogo etc., elegendo como modelo, entre muitos outros, o especialista dos caçadores tunguses da Sibéria. ${ }^{10}$

Uma das mais intensas críticas provém de Roberte Hamayon (1993), que invalida a categoria de "transe" enquanto contato direto com os "espíritos", ao considerar que remeteria à psicologia individual que não nos informa sobre o contexto simbólico no qual transcorre, ${ }^{11}$ ao mesmo tempo em que a considera carregada de conotações pejorativas sobre os "primitivos". Supõe que, ao se falar em transe, se está adjudicando uma conduta irracional e inferiorizante ao "outro" cultural, carregada de misticismo, mas sua reflexão, mais que um juízo acadêmico, é um preconceito pessoal sobre o misticismo. Assinala que os assim denominados xãmas não são indivíduos particularmente especiais e marginais, mas dependentes de um contexto social e simbólico específico, ou seja, "descobre" que o xamanismo constitui 
um desempenho social pautado pela cultura e ressalta que este contexto é normalmente constituído por sociedades caçadoras nas quais o xamã dialoga com os animais.

Ainda que não sugira nada que Durkheim já não tenha dito quanto ao social e que há mais de meio século foi desenvolvido por Lévi-Strauss, no que concerne à eficácia simbólica da prática xamânica que deriva do reconhecimento social (1968[1949]), sua proposta da relação do xamanismo com as sociedades caçadoras não suporta a confrontação com a evidência etnográfica das terras baixas sul-americanas, nas quais se registram práticas xamânicas em sociedades agricultoras (M. Bartolomé 1977, 2000, 2009; Reichel Dolmatoff 1978; J. Langdon 1996). Por exemplo, a sociedade guarani é uma sociedade polissegmentada de agricultores tropicais, constituída por pequenas chefias, cujos líderes políticos, parentais e religiosos são sempre xamãs, já que estes três âmbitos se vinculam em uma mesma esfera de realidade (M. Bartolomé 1991 [1977]). O mesmo pode ser dito à arqueóloga Joyce Marcus (2002), que nega a existência do xamanismo na Mesoamérica, por ser esta uma instituição própria das sociedades caçadoras e igualitárias, que não seria pertinente em culturas estratificadas e hierárquicas. Neste caso, a autora deveria explicar a amplamente documentada existência do xamanismo não somente no passado e no presente da Mesoamérica, mas também entre os agricultores da altamente estratificada tradição civilizatória andina, vinculada inclusive ao uso ritual de enteógenos desde as evidências mais remotas existentes (J. Schobinger 1997).

Desta forma, tanto a evidência das terras baixas como das terras altas sul-americanas faz com que não consideremos o xamanismo como resíduo de uma religião arcaica de caçadores, e sim como uma instituição social dinâmica que pode ser registrada em distintos tipos de sociedades, na medida em que cumpra uma função socialmente legitimada. ${ }^{12}$ Em outras palavras: o xamanismo e a técnica do transe não são uma patologia; trata-se de uma prática social institucionalizada, desempenhada por alguns indivíduos dotados de uma vocação especial. Isto lhes permite desenvolver uma conduta carismática que lhes possibilita atuar como curadores, guias rituais ou mesmo como líderes políticos. Seu poder representa uma delegação que a sociedade deposita nele, baseando-se em seus princípios e lógicas culturais. O xamã não cria as lógicas simbólicas, mas as reproduz, as enuncia nos relatos e as coloca em prática.

Desde 1965 (1968, 1980,1996) Peter Furst, baseado na leitura de Mircea Eliade e na extrapolação de sua experiência com os Huichóis, generalizou a presença do nagualismo e do xamanismo na Mesoamérica pré-hispânica, mas considerando-os, uma vez mais, "como substrato arcaico de caçadores 
coletores" (1980 [1976]:176), propondo a importância central do uso das drogas enteógenas na configuração dos sistemas políticos e religiosos estatais. Como já assinalamos, a questão do substrato arcaico supõe uma adjudicação de primitivismo ao xamanismo que está longe de ser demonstrada, já que coexiste, e coexistiu, com religiões estatais. Cecilia Klein et al. (2002) criticaram duramente esta perspectiva, inspirados em Roberte Hamayon, mas assumindo que considerar os antigos líderes políticos como xamãs é uma forma de menosprezá-los. Esta proposta é um tanto ingênua, já que, em sociedades nas quais o nomos (a ordem significativa da sociedade) está associada ao cosmos (a ordem significativa do universo), a distinção entre política e religião é muito ambígua, uma vez que se trata de uma mesma ordem, e a valoração do político sobre o religioso estabelecida pelos autores é, para dizer o mínimo, ocidentalocêntrica. ${ }^{13}$

A obra de Hamayon (1990) também foi recolhida no México por um de seus discípulos, o famoso etno-historiador Roberto Martínez González (2009), que questiona o êxtase xamânico enquanto "modelo neuropsicológico" (2009) individual, mas universalizante, que negaria o específico de cada cultura. Trata-se da mesma argumentação que nega que o transe ou o êxtase seja constitutivo do xamanismo, quando, na realidade, é o sistema simbólico preexistente que lhes outorga sentido. Como vimos no começo deste ensaio, esta foi precisamente a crítica de Durkheim ao animismo. O individual inscreve-se no marco do social e do cultural; não acreditamos ser necessário reiterá-la mais de um século depois. Mas estas críticas ao suposto universalismo xamânico fazem com que o autor negue a pertinência da categoria como um conceito generalizante e propõe sua substituição pelas categorias locais, partindo da hipotética incapacidade nomotética das ciências sociais, com a qual não podemos estar de acordo, se não quisermos voltar ao mais arcaico dos particularismos etnográficos.

As evidências arqueológicas e etno-históricas mesoamericanas demonstram de modo consistente que o xamanismo formou parte das religiões estatais em distintos momentos da milenária história desta tradição civilizatória. No caso maia, uma das altas divindades, Itzamná, foi a fundadora da instituição xamânico-sacerdotal, que proporcionava a divina substância celeste, Itz, que fluía através do portal que abria o altar dos xamãs na Terra. Esta comunicação permitia, e permite, que Itz - lágrima, resina, gotas de vela, gotas de suor, saliva, essência — chegasse ao plano terrestre e auxiliasse a humanidade (D. Freidel et al. 1999:47). Os mesmos autores, renomados especialistas, assinalam que tanto os líderes políticos como religiosos maias do passado eram xamãs, ainda que os xamãs de agora se limitem à cura e à liderança ritual nas cerimônias para pedir chuva ou benzer a terra. 
Não há dúvida quanto à existência de xamãs maias, apesar de os chamados Chilamob, os intérpretes, que recorriam a estados de transe para profetizar ou adivinhar, serem os que com maior precisão se aproximam da definição tradicional da prática. Na atualidade, os possuidores do "alto conhecimento" especializado das religiões estatais se converteram em xamãs e sacerdotes de uma tradição camponesa cujas práticas lembram as de seus antecessores (M. Bartolomé 1988). Evidências ainda mais claras de xamanismo institucionalizado são registradas nos señoríos zapotecos do pós-clássico, tal como documentou o cronista Francisco de Burgoa, ao se referir ao principal sacerdote oficiante na cidade sagrada, necrópole, de Mitla (Liobaa, em zapoteco), em Oaxaca, cujo nome revelador era precisamente Uija-tao, grande vidente, e cuja prática evidencia um tipo de transe xamânico, como relata o cronista (1989, T.II:121-125):

[...] e vestido chegava com imponência e gravidade ao altar, fazia grandes reverências aos ídolos, renovava os incensos e punha-se a falar entre dentes com aquelas figuras, depósitos de espíritos infernais. Neste tipo de oração perseverava com gestos disformes, bramidos e movimentos, que causavam em todos os presentes temor e assombro, até que voltava daquele rapto diabólico e contava aos presentes as ficções e mentiras com as quais o espírito o persuadia ou ele inventava...

O registro arqueológico da tradição mesoamericana, o etno-histórico e especialmente o etnográfico das culturas indígenas atuais do México nos demonstram, para além de qualquer dúvida razoável, a existência de um tipo de especialistas que podemos qualificar ou conceitualizar como xamãs com base em algumas de suas capacidades compartilhadas: a) a existência de uma iniciação que costuma adotar a forma de uma morte ritual, de uma grave enfermidade ou, frequentemente, de um sonho recorrente, ao longo do qual o indivíduo recebe o "dom" que lhe permite tornar-se xamã. A esta iniciação se segue um aprendizado guiado por um xamã mais velho; tal aprendizado é por vezes negado, visando enfatizar o caráter sagrado ou extra-humano das faculdades que possuem; b) a capacidade de manejar voluntariamente o transe autoinduzido ou provocado por psicotrópicos e em especial - os sonhos, para viajar animicamente e comunicar-se com as entidades que habitam o espaço-tempo paralelo, âmbito cuja natureza é um construto simbólico conhecido pelo conjunto da cultura; e c) a possibilidade de dialogar, combater, negociar, utilizar ou manipular os aspectos anímicos das entidades extra-humanas com fins curativos, agressivos, rituais ou divinatórios, sejam estes entidades, divindades ou os componentes não materiais da totalidade dos entes que compõem o universo. 
No caso da Mesoamérica, o xamã era, e é, um especialista entre outros ritualistas, e a sociedade não se definia — nem se define — por sua presença, ainda que sua importância tenha variado nos distintos momentos históricos, especialmente naqueles afetados por alguma crise. Assim o comprova o já mencionado papel de liderança que os xamãs assumiram nos distintos movimentos messiânicos, tanto naqueles de resistência à invasão europeia como nas rebeliões anticoloniais, incluindo as posteriores à independência estatal (A. Barabas 1989).

$\mathrm{Na}$ atualidade, o xamanismo é um aspecto das culturas locais que foi objeto de um reducionismo nivelador, ao pretender designar um vasto conjunto de especialistas na manipulação do sagrado sob um denominador comum, ao qualificá-los como bruxos, curandeiros ou feiticeiros. Como bem declarou Julio Glockner (2004:42):

[...] Suspeito que o xamanismo mesoamericano tenha sido evitado devido ao fato de dois temas fundamentais de sua caracterização terem sido subestimados até muito recentemente: os sonhos e o emprego ritual de enteógenos... Não é casual, tampouco, que as revelações oníricas continuem tendo um papel de primeira importância entre os demandantes de chuva dos grandes vulcões do altiplano. Os sonhos são uma fonte inesgotável da qual emanam imagens, símbolos e indicações precisas em torno dos quais se organiza a atividade ritual dos trabalhadores do temporal...

Na maioria das culturas indígenas contemporâneas do México há xamãs, mas poucos destes especialistas utilizam as práticas que definiriam em um sentido estrito o xamanismo, ou seja, é uma relativa minoria que recorre, nos dias de hoje, ao transe ou aos estados alterados de consciência, autoinduzidos ou derivados da ingestão de enteógenos, para comunicar-se com o espaço-tempo alternativo. Em nosso âmbito, são muito mais frequentes o sonho, os estados de não vigília ou sonho diurno e a adivinhação por meio de distintas técnicas, como formas de comunicação e interação com a realidade não ordinária ou extra-humana, o mundo paralelo, tal como caracterizamos o espaço-tempo das entidades anímicas.

A maioria dos estudos sobre o tema enfatizou o papel de curadores dos xamãs, talvez o mais visível, ainda que não o único, tal como se adverte na recente antologia coordenada por Antonella Fagetti (2010), na qual estão presentes tanto o sonho como o mito e os símbolos compartilhados, mas que continua destacando a função de cura. De natureza similar é a antologia editada há uma década por B. Huber e A. Sandstrom (2001), especificamente dedicada às práticas curativas mesoamericanas, ou a ainda mais recente obra 
coordenada por Laura Romero López (2011), em cujo título se equipara o xamanismo ao curandeirismo, ainda que nem todos os ensaios que integram a antologia se centrem na função de curador. E precisamente uma das condutas que diferenciam os curadores dos xamãs é o papel que estes últimos costumam desempenhar na vida ritual e política de suas comunidades.

A liderança ritual admite muitas considerações. Quando um h-men (um fazedor) maia guia um cha' chaác, uma cerimônia para pedir chuva, não está realizando somente uma mediação entre a comunidade de participantes e as entidades extra-humans, mas sim apelando para os princípios cosmogônicos e cosmológicos da cultura para reinstalar o princípio ordenador do cosmos, cuja falha se manifesta pela ausência de chuva. De modo análogo, quando cura um paciente, está restaurando a ordem, o nomos social, cuja transgressão - voluntária ou involuntária - produziu a enfermidade. Ou seja, em ambos os casos, ritual coletivo e cura, opera o mesmo princípio ontológico: a necessidade de manter a ordem de significados que define os sentidos da cultura. Mas em uma situação colonial, marcada pela necessidade de ocultamento e clandestinidade das práticas para mantê-las à margem do dominador, é frequente que se chame mais a atenção para o papel do curador do que para o de guia de condutas coletivas. É por esta razão que o papel político, social dos xamãs é menos visível na atualidade do que no passado, ainda que isto não queira dizer que tenha desaparecido. Tanto entre os Mixtecos como entre Mixes, Chinantecos, Mazatecos, Nauas, Huichóis e outros grupos, os xamãs continuam guiando os rituais domésticos e coletivos e, em certas ocasiões, legitimando os líderes políticos.

Tradicionalmente, destacou-se que o xamanismo se baseia em uma teoria da comunicação entre os dois mundos, um terreno e o outro extrahumano, isto é, entre o âmbito do poderoso - aquilo que costumamos chamar de sagrado - depositário da ordem, e o do secular, marcado por certa "desordem" ou incerteza. A generalização unitária do uso do termo pode confundir um conjunto distinto de especialistas, cujas práticas rituais ou terapêuticas não se referem necessariamente a um modelo unificado. Por outro lado, a presença de xamãs em nosso âmbito não nos autoriza — com poucas exceções - a falar em religiões xamânicas, como as que, com frequência, são registradas entre muitos povos da América do Sul tropical. As exceções talvez estejam representadas pelos Huichóis, entre os quais os maracames desempenham uma liderança política e ritual, ou os Mazatecos, em que a ingestão de enteógenos com finalidades rituais não se limita aos especialistas, sendo uma atribuição de todos os chefes de unidades domésticas.

Em ambos os casos, podemos falar não somente em sociedades com xamãs, mas talvez em sociedades xamânicas, devido à importância do 
papel social de tais especialistas. Por outro lado, como já assinalamos, não acreditamos que a vigência de especialistas e práticas xamânicas possa ser considerada em termos evolucionistas lineares, como uma sobrevivência arcaica das sociedades anteriores ao desenvolvimento da tradição civilizatória mesoamericana, e sim como uma instituição que possui uma lógica específica dotada de grande dinamismo, que mantém sua eficácia nos diversos e cambiantes contextos históricos. Jacques Galinier e Michel Perrin (1995:XV) preferem conceitualizá-la como “[...] um sistema intelectual cuja plasticidade é tal que permite diversas formas de coabitação, de interpretação ou de coexistência com as grandes doutrinas de salvação [...]". Assim, por exemplo, em outras latitudes, temos o xamanismo coexistindo com o budismo tântrico do Tibet e com o islamismo imposto aos povos Bereberes do norte do Saara e, na América do Sul, com as grandes e complexas formações estatais andinas.

No México, encontramos diversos tipos de especialistas na manipulação do extra-humano e, com isto, nos referimos à capacidade de mobilizar símbolos culturais dotados de uma qualidade especial de potência. Assim, os distintos especialistas, como curadores, feiticeiros, adivinhos ou xamãs, compartilham o fato de suas tarefas suporem distintos tipos de inserção ou de vínculo com a esfera das entidades extra-humanas poderosas ("o sagrado"). O mundo secular ou cotidiano não equivale necessariamente à desordem, e sim à incerteza e, neste sentido, as práticas dos especialistas supõem um chamado à ordem cósmica e social associadas para restaurá-la ou impedir o aparecimento da desordem. A sociedade não pode renunciar ao anseio por uma ordem primeva proposta nas cosmologias, que construiu de modo inicial e normativo o edifício cósmico e social que habita cada cultura concreta. É por esta razão que os especialistas na manipulação do sagrado, tanto com suas ações como com seus discursos, refrescam a memória das sociedades, conectando-as às milenárias ideações que sustentaram suas cosmovisões.

Não se trata somente, como o qualificou Eduardo Viveiros de Castro (2002), de um "diplomático cósmico", termo que pretende ser extrapolado ao México, já que muitas vezes é muito pouco diplomático. Dependendo da cultura, em certas ocasiões, o xamã regressa machucado porque teve de lutar; em outras, é um servil suplicante que só pretende adular as entidades poderosas; há até mesmo alguns que as insultam para humilhá-las e com isto alcançar seus objetivos. ${ }^{14}$ Não falta aquele que dialoga, expondo razões; outros somente se dedicam a resgatar entidades anímicas perdidas por seus donos, existindo, por fim, uma grande variedade de formas de negociação possíveis. É um intermediário, mas a mediação pode adotar formas diversas. 


\section{Tonalismo, nagualismo e xamanismo}

Uma complexa noção cosmológica que está presente na grande maioria das culturas indígenas do México é aquela conhecida como tonalismo e nagualismo, ainda que se manifeste com diferentes características em cada uma delas. Tal concepção propõe uma "teoria das almas", segundo a qual os seres humanos têm uma ou mais entidades anímicas companheiras, quer sejam animais ou fenômenos atmosféricos (raios, trovões, centelhas etc., concebidos também como entidades anímicas), que nascem junto com o indivíduo e que serão suas coessências durante toda a existência, constituindo uma força vital externa, mas associada à vida humana. De acordo com esta teoria, todos os seres humanos possuem um tonal, uma força vital que o acompanha, mas somente uns poucos são dotados da capacidade de se transformar em seu alter ego, o que se conhece como "nagualismo", na língua náhuatl.

O tonalismo e o nagualismo são algumas das concepções mais antigas da tradição civilizatória mesoamericana, já que as encontramos plasticamente representadas nas esculturas da chamada "cultura mãe" olmeca, em datas que remontam a mais de 30 séculos (M. Coe 1965). Para os Olmecas, tal como para as culturas que durante milênios deram continuidade e reproduziram as concepções mesoamericanas até o presente, a entidade preferida, tanto como coessência como tendo em vista a transformação, é o jaguar (P. Furst 1968), um animal emblemático em todas as populações ameríndias. Há uma razão evidente para se propor a relação de poder de certos indivíduos com o jaguar, já que este é, em toda a América Central e do Sul, o único caçador que caça o homem. Por esta razão é um igual e um rival, um "outro", tão temido quanto admirado, entidade que se cultua, ao mesmo tempo em que se pretende emular. ${ }^{15}$

Muitos dos altos dignitários das configurações estatais mesoamericanas se vestiam com peles de jaguar, incluíam-no em seus nomes ou para ele erigiam representações em pedra. Na área maia yucateca, inclusive, o próprio termo que designa o jaguar, balam, também alude ao oculto, ao extra-humano, ao que chamaríamos de "sagrado". Assim, o templo construído pelos rebeldes maias que protagonizaram a massiva insurreição do século XIX, conhecida como "guerra de castas", denominava-se, precisamente, Balam Nah, "casa ou morada do jaguar ou do oculto" (M. Bartolomé \& A. Barabas 1981 [1977]). De fato, o nome do antigo xamã, adivinho e profeta, que recorria ao estado de êxtase para suas práticas oraculares era precisamente Chilam Balam, "o que é boca do oculto".

Para os maias do período clássico (cerca de 300-900 D.C.), a presença de uma noção de coessência é marcada pelo glifo way, etimologicamente vinculado à transformação em animal, ao sonho, à bruxaria e às visões 
(S. Houston \& D. Stuart 1989). Ao que parece, a tradução do termo náhuatl nahualli seria aproximadamente a de máscara ou disfarce, ou seja, o indivíduo transformado se converte em seu outro, se reveste metaforicamente com a sua pele (A. López Austin 1972). De acordo com este autor, o termo nahual poderia ser traduzido como "o que é meu traje". Os textos antigos referemse aos homens-deus como ixiptla do deus protetor, ou seja, sua "imagem", "delegada", "substituta" etc., já que a palavra ixiptla pode ser traduzida como "pele", "cobertura" ou "casca", equivalente, então, ao nahualli (1972:118119). Isto seria confirmado pelo atual termo mixteco tnuu para designar os naguais, que pode ser traduzido como negro ou máscara, ou nuutnuu "algo negro que cobre a cara" (dados de campo).

Os atuais Chinantecos de Oaxaca, grupo no qual o nagualismo tem vigência extraordinária, também designam um tipo especial de "bruxos" naguais como "homens couro", dzäläan, ou seja, pessoas revestidas, termo no qual a partícula lä alude ao poder de transformação (M. Bartolomé et al. 1999, Vol. II:78). De acordo com o dicionário colonial zapateco de Córdoba, escrito por volta de 1578, a palabra zapoteca para "bruxo" é huecháa, é um nagual, já que alude ao que "se transforma" ou "ao que muda" (D. Augsburger 2003:247), conceito que continua sendo utilizado na atualidade. Vemos então que, dentro de sistemas sociorreligiosos altamente estruturados por suas classes dirigentes e sacerdotes e reproduzidos através da escrita, estas noções milenares eram parte de uma ideologia social tanto estatal quanto popular.

O transformismo ou a metamorfose de seres humanos em animais, ou vice-versa, é uma noção registrada, possivelmente, em todas as culturas do mundo, e que podemos ver plasticamente representada nos mais antigos desenhos do Egito ou da Mesopotâmia. O mesmo ocorre na maioria das tradições ameríndias. Contudo, o nagualismo não equivale a todo transformismo. Dentro da tradição mesoamericana, aparece como uma concepção cultural e politicamente formalizada de modo singular e vinculada ao poder político. Tratava-se de um princípio cósmico ao qual correspondia uma contrapartida social (ou vice-versa). As próprias divindades tinham duplos ou alter egos companheiros, tal como o testemunha, por exemplo, e para sairmos da casuística naua, um mito cosmogônico dos Mixtecos, recolhido pelo cronista Fray Gregorio García, no qual narra o nascimento dos irmãos gêmeos, filhos do casal primordial:

O primeiro se chamou Senhor 9 Vento Cobra (emplumada). O segundo se chamou Senhor 9 Vento Yahui (Serpente de Fogo). Estas duas crianças foram criadas com muita alegria: o nagual do mais velho era uma águia (yaha) que andava voando pelos altos, o nagual do segundo era uma serpente alada (yahui), 
que voava pelos ares com tanta agilidade e sutileza que entrava pelas rochas e paredes e se tornava invisível (apud M. Jansen \& G. Pérez Jiménez 2008:91).

Do mesmo modo que as entidades divinizadas, seus representantes terrenos, descendentes das divindades, as classes governantes e sacerdotais também possuíam poderosos duplos e a capacidade de transformação que legitimava seu poder terreno em nível cósmico. A iconografia pré-hispânica é abundante em imagens de divindades acompanhadas de suas coessências, assim como de líderes políticos e religiosos junto aos quais se infere a presença de seus duplos. Recordemos que os chefes políticos ou religiosos, muitas vezes o mesmo indivíduo, eram representantes das divindades, já que seguiam o modelo de conduta herdado do herói cultural, de acordo com a tradição mesoamericana do Homem-Deus (A. López Austin 1972). Em especial, as sociedades que desenvolveram sistemas calendários, nas quais a carga de poder ou energia solar do dia ficava associada ao indivíduo que nascia naquela data, parecem ser as que com maior ênfase desenvolveram e conservaram - até o presente - esta tradição, que as formações estatais transmitiram às pessoas comuns, já que, se não as conheciam, não podiam influir sobre elas. O nagualismo aparece, assim, ligado não somente às concepções cosmológicas, mas também às lógicas políticas próprias de sociedades estratificadas e altamente hierarquizadas.

Os naguais dos líderes e altos sacerdotes eram defensores de seus povos mas, ao mesmo tempo, uma recordação das capacidades extra-humanas que impunham temor aos que estavam sob sua influência. A condição definidora do nagual era a transformação, que lhe permitia incursionar no mundo alternativo pelo espaço-tempo paralelo, e ali defender as entidades anímicas de sua comunidade, ou agredir os alter egos inimigos de sua gente. Trata-se de um típico poder dual e xamânico; para seus defendidos, era um benfeitor, mas para seus inimigos, um terrível predador.

Poderíamos entender a noção de nagualismo na tradição mesoamericana como um complexo cultural integrado por um conjunto específico de traços, que podem estar presentes em outras culturas, mas que aqui manifestam uma associação singular. Os traços sintetizam-se na noção de que as divindades e algumas pessoas possuem duplos e coessências vitais nas quais podem se transformar. Esta capacidade constitui um modelo de legitimação cósmica e social para os líderes políticos e religiosos (não muito diferenciados), razão pela qual ganha contorno em configurações institucionais em distintos momentos históricos, em diferentes culturas de tal tradição. Em outras palavras, o nagualismo implica um conjunto de representações coletivas acerca do fato de se possuir uma dupla identidade, 
ao mesmo tempo cósmica e social, que constitui o substrato das crenças que orientam um aspecto das ideologias das formações estatais mesoamericanas. Nelas, o nomos e o cosmos são coextensos e conformam uma mesma noção de realidade, na qual os naguais têm a capacidade de se tranformar para transitar, comunicar e atuar sobre tudo o que existe. ${ }^{16}$

Tal como demonstra o registro etnográfico, a maior parte das culturas indígenas contemporâneas possui sua própria concepção sobre o tonalismo e o nagualismo, na qual também se sustenta a construção da noção de pessoa social (M. Bartolomé 1997). Nos dias de hoje, é frequente que as duas noções se encontrem unificadas, formando parte de uma mesma esfera conceitual referida à potência das coessências anímicas, e o termo nagual designa tanto o alter ego como a capacidade de "mudança" neste último. Este é o caso dos atuais Zapotecos das montanhas, para quem o mesmo conceito bxej designa tanto o animal companheiro como a capacidade de transformação.

Tal como se enuncia no registro etnográfico, assim como em nossa própria experiência, é muito difícil ter acesso a uma formulação definida a respeito deste tema. Trata-se, em geral, de concepções e experiências vividas, mas não sistematizadas, que se encontram fragmentariamente contidas em relatos, narrações e anedotas de circunstâncias concretas nas quais os indivíduos tiveram relação com seus alter egos, tiveram notícias de transformações ou de ações nagualistas. Mais do que uma construção "teórica" derivada da presença e da exegese de especialistas, trata-se de um fenômeno ligado à experiência individual e social, que o reproduz e o difunde, razão pela qual a teoria sobre estas antigas noções culturais deve ser elaborada pelo investigador, ainda que em tal elaboração se leve em conta o "ponto de vista nativo". São relatos de experiências cotidianas nas quais o "outro mundo", o âmbito das entidades extra-humanas, fez contato com este nível da realidade e permitiu aos seres humanos confirmarem as provas de sua existência e de sua potência.

Para um observador externo, é muito difícil compreender a vivência social do nagualismo, ainda que se chame a atenção para o fato de que as entidades anímicas são motivo recorrente para intrepretar os acontecimentos que afetam a coletividade, seja porque sua presença desperta um sentido de proteção ou de temor, ou porque exibe um aspecto ameaçador da realidade alternativa; mas é evidente que os povos indígenas têm nesta noção uma chave para o conhecimento profundo de diferentes aspectos da realidade, cujas manifestações exteriores são vistas como mera aparência das verdadeiras forças que subjazem aos fatos. Uma morte inesperada, um acidente que faz com que uma pessoa caia na água e se afogue, a presença de uma epidemia, alguma praga que afeta as plantações, mudanças inesperadas 
nos desempenhos das autoridades municipais, a conduta errática de um indivíduo em relação à sua família e vizinhos, a vontade de aceitar algum benefício apesar da carência de recursos, e até o nascimento de crianças defeituosas podem encontrar na ação dos naguais sua explicação última.

Se temos dedicado tanto espaço a esta concepção é porque tratamos de definir qual é o aspecto anímico do xamã que se transporta ao Mundo Outro e que, em grande parte dos casos, é precisamente seu nagual. Tratase, então, de um componente fundamental da prática xamânica histórica e contemporânea. Há mais pesquisas em curso e deve-se continuar analisando detidamente as relações entre o nagualismo e o xamanismo nas culturas do México. Do nosso ponto de vista, proporíamos que o tonalismo-nagualismo, em um de seus níveis, comporta-se como uma categoria construtora da pessoa, ou seja, como um dos componentes da noção social da pessoa. Mas o fundamental é que a categoria fornece as bases para a aquisição de poderes não ordinários, poderes xamânicos que permitem a comunicação com as divindades e a capacidade de ação sobre as entidades anímicas dos indivíduos e da coletividade. Por sua vez, a transformação nagualista funciona como a capacidade de comunicar distintos domínios ontológicos, os diferentes âmbitos da realidade e possibilita a interação entre eles, tal como o faz o transe ou o sonho xamânico. É frequente que os xamãs narrem que, em suas viagens oníricas ou transes enteogênicos, podem ter acesso ao mesmo mundo pelo qual transitam os naguais; de tal relação deriva seu poder de atuar sobre eles no caso de anular ações malignas.

De fato, alguns estudos de caso, como o realizado por June Nash (1961) entre os Maias tzeltales e tzotziles de Chiapas, propõem que o nagualismo é a força do poder do xamanismo, já que é por meio da transformação que se consegue a comunicação com outra realidade, ainda que localmente sejam mais temidos que respeitados. A capacidade de transformação dos especialistas na vinculação com o extra-humano foi precisamente o poder mais temido e combatido pelos evangelizadores católicos, já que muitos sacerdotes não o consideravam somente uma superstição nativa, mas acreditavam nele como manifestação dos poderes demoníacos que lhes atribuíam. Como consequência desse processo de repressão histórica, agora, o nagualismo aparece frequentemente mais associado à bruxaria do que às práticas curativas e rituais xamânicas. Assim, muitos xamãs negam ter ou ser naguais.

Na atualidade, o registro etnográfico demonstra que muitos daqueles que poderíamos considerar xamãs baseiam sua prática no poder de seus naguais, como no caso dos Mixes, Chinantecos, Nauas, da Serra Norte de Puebla e de Zongolica em Veracruz, ou dos Maias de Chiapas. Mas nem em todos os grupos se associam os especialistas desta natureza à transfor- 
mação. As evidências tornam válido sugerir que o nagualismo constituía e ainda constitui - em muitos casos - um dos componentes específicos que outorgam singularidade ao xamanismo mesoamericano. No entanto, nem todos os xamãs são agora dotados da capacidade do nagualismo. Todo nagual é, ou pode chegar a ser, um xamã, mas nem todos os xamãs precisam ser naguais. Esta capacidade, demonizada pelo colonialismo, foi restrita, mas não desapareceu; os alter egos da humanidade continuam transitando pelo universo paralelo, comunicando planos da existência, obtendo conhecimentos, poderes, capacidades de cura, possibilidade de inflingir danos, dados dos repertórios culturais que lhes permitem liderar as comunidades rituais e, por fim, influenciar a vida coletiva, como o fizeram durante milênios.

Recebido em 07 de fevereiro de 2013

Aprovado em 14 de fevereiro de 2013

Tradução de Roberta Ceva

Miguel Bartolomé é professor do Instituto Nacional de Antropologia e História do México - Centro Oaxaca. E-mail: <barbar2@prodigy.net.mx>

Alicia M. Barabas é professora do Instituto Nacional de Antropologia e História do México - Centro Oaxaca. E-mail: <barbar2@prodigy.net.mx>

\section{Notas}

${ }^{1}$ Daqui por diante, quando nos referirmos ao "registro etnográfico", estaremos falando dos resultados da Linha de Pesquisa sobre Xamanismo e Nagualismo que coordenamos dentro do Projeto Etnografia das Regiões Indígenas do México, da Coordenação Nacional de Antropologia do INAH, entre 2008-2009, guiando o trabalho de uma centena de pesquisadores em todo o país.

${ }^{2}$ Em muitos ensaios etnográficos podem ser encontradas referências mais ou menos extensivas aos sonhos. Entre os textos escritos especificamente a este respeito, e sem pretendermos ser exaustivos, encontram-se os livros sobre os Maias lacandões de Robert Bruce $(1975,1979)$. Há também um ensaio pioneiro de George Foster, referente aos Purépechas (1973) e um mais contextualizado de William Merrill (1987) sobre os Rarámuri. Robert Laughlin (1976) tentou aprofundar a questão do 
sonho entre os Maias zinacantecos. Mais recente, ainda que já tenha 20 anos, é a importante obra sobre os Nauas e os Maias de Mercedes de la Garza (1990). Marie Odile Marion (1996) produziu outro aporte sobre os lacandões, Glockner (1997) sobre os tiemperos (controladores do tempo) e Juliette Roullet (2003), um texto, um tanto especulativo, sobre os Maias de Chiapas. Esta não é uma lista completa, mas dá conta do crescente interesse pelo tema.

${ }^{3}$ A palavra transe provém do latim transire, que se traduz como transitar, transportar-se, cruzar, e os múltiplos significados de seu parônimo "entrada", relacionado com umbral, conduto, portal. As experiências conhecidas como "cair ou entrar em transe" referem-se a um mecanismo psicológico no qual a pessoa se abandona a certas condições externas ou internas e experimenta um estado de consciência diferente. Os estados de transe são sempre acompanhados por modificações sinestésicas e neurovegetativas e estão relacionados com o conceito de iluminação espiritual. Êxtase, do latim extasis é entendido como a fase supraintelectual da ascensão mística em direção a Deus, caracterizada pela contemplação. Do ponto de vista filosófico, a noção se desenvolveu entre os neoplatônicos, chegando até os místicos alemães do século XIV. Contemporaneamente, distingue-se o êxtase religioso determinado por condições anormais de vida psíquica e física (jejum, flagelo, isolamento etc.) do induzido por drogas. A psicologia e a psiquiatria assinalaram que se manifesta com três características essenciais: a supressão quase completa da atividade motora e disposição para a imobilidade, uma atividade mais ou menos intensa do pensamento interno e um grande sentimento de gozo. Desde Heidegger e Sartre, êxtase é entendido como "estar fora do tempo" (Abbagnano 1963:513).

${ }^{4}$ Os casos relatados no registro etnográfico de alguma forma de possessão de uma entidade por outra se concretizam entre os Nauas de Zongolica; entre os xamãs "árvores" nauas de Morelos, que são possuídos pelos espíritos do temporal (chuva), aos quais brindam com corpo e voz; e entre os xamãs otomi de Hidalgo; Otomis, Nauas, Teenek e Totonacos da Huasteca, que tornam possível a possessão dos corpos-fetiche por parte das entidades extra-humanas; e os Otomis chichimecas de Querétaro, entre os quais o xamã esculpe massas de milho cozido nas quais encarna as entidades extra-humanas.

${ }^{5}$ Coincidimos nisto com Mercedes de La Garza (1990:21), que enfatiza sua certeza de que existe um vínculo essencial entre os estados alterados da consciência e os sonhos entre Nauas e Maias. Em muitas culturas com as quais nos relacionamos, os estados de transe produzidos pelas substâncias psicoativas nos foram narrados como similares aos sonhos (M. Bartolomé \& A. Barabas 1981). Entre os Avá-guarani do Paraguai, os xamãs desenvolvem suas práticas por meio de sonhos autoinduzidos, expressamente buscados (M. Bartolomé 1991 [1977]). No caso dos indígenas Siona do Putumayo colombiano, as visões produzidas pelo psicotrópico yagé são consideradas análogas à experiência do sonho, já que permitem aceder à mesma realidade alternativa (J. Langdon 1996).

${ }^{6}$ No Código Florentino, tal como é conhecido o Tratado geral das coisas da Nova Espanha, de Fray Bernardino de Sahagún (cerca de 1580), o escriba naua que narra a peregrinação dos Mexica afirma que "[...] logo [que] inventaram o cálculo dos 
destinos, o livro dos anos, o cálculo dos anos, o livro dos sonhos, entraram em acordo sobre a forma como seriam conservados" (tradução de A. López Austin 1994:233).

7 Dolores Aramoni (1990:51-52), em um estudo sobre os Nahua de Puebla, afirma que: "[...] Ainda quando as causas imediatas e evidentes que desencadeiam a síndrome do susto são pessoas, animais ou elementos [...], a causa última do susto é o acaso manipulado pela ordem divina". Os verdadeiros agressores do tonal são forças sobrenaturais presentes no momento e no lugar em que uma pessoa, voluntária ou involuntariamente, ultrapassa a sutil linha divisória que separa o mundo humano do divino, profanando-o. Acredita-se que, ao "molestar" os "donos" da terra, dos rios e lagos, dos bosques ou dos animais, estes capturam e tomam o controle sobre o tonal do transgressor. Sua liberdade e retorno dependem então da expiação da afronta; a eles se deve suplicar e fazer oferendas para que o liberem [...]".

${ }^{8}$ As referências etno-históricas podem, inclusive, ser ambíguas. Para os antigos Naua supõe-se que Tamoanchan era um tipo de paraíso, lugar da criação, origem da vida e do milho, ao passo que Tlalocan era um âmbito de morte, para o qual iam os tombados pelo raio ou pelas águas. No entanto, ambos os espaços confundem-se e se desdobram. Não são céu e inferno, como acreditavam os primeiros missionários, mas talvez aspectos distintos de uma mesma construção mítica, ou talvez de um mesmo mundo alternativo com distintas qualidades às quais têm acesso os sonhadores (ver v.g., A. López Austin 1994:9).

${ }^{9}$ Não podemos deixar de citar uma caracterização documentada do "inframundo" dos Zoque de Chiapas, realizada por nosso colega ayuuk (mixe) Laureano Reyes (2008). Graças a seu conhecimento da língua, bastante próxima da sua, este pesquisador determinou a existência de quatro mundos alternativos que, na realidade, constituem distintos momentos do ciclo solar. O âmbito da vida terrestre, o âmbito das entidades anímicas regido pelo Senhor do Monte que é possível visitar em sonhos, o mundo labirinto onde se dá continuidade à vida terrestre e o mundo da obscuridade, habitado pelos suicidas. Mas todos não são senão fases do mesmo trânsito solar, um mesmo ciclo com distintas manifestações.

${ }^{10}$ É um lugar comum mencionar que Mircea Eliade baseou-se exclusivamente no modelo proporcionado pelos Tunguses, mas para além de constituir um lugar comum, esta afirmação é falsa. Para construir o conceito, utilizou a denominação dos Tunguses mas recorreu a uma casuística que incluía povos da Sibéria Ocidental e Central, Ásia Central e Setentrional, Sudeste da Ásia, Austrália, América do Sul, Caribe, América do Norte, África, Indonésia, Oceania, Tibete, China e diversos grupos indoeuropeus. Isto não implica aceitar a formulação boasiana de que a soma dos dados geraria a teoria, e sim que a erudição do autor merece mais consideração do que aquela que lhe atribuem alguns críticos. A respeito do uso do termo transe, refere-se a um amplo conjunto de fenômenos similares em distintas culturas, razão pela qual segue sendo de utilidade para nomear de forma genérica os estados de consciência alterados dos xamãs.

${ }^{11}$ É indubitável que a autora, como muitos outros colegas, reage implicitamente contra as modas contraculturais da década de 1960, que consideravam que qualquer 
um que ingerisse psicotrópicos poderia alcançar um estado xamânico, independente de sua filiação cultural. As obras do romancista Carlos Castañeda foram bastante danosas a este tipo de estudos, ao generalizar um misticismo ingênuo em torno de um tema que merece tratamento científico.

${ }^{12}$ Jean Langdon (1996:29) sintetiza as características do xamanismo das terras baixas sul-americanas em termos coincidentes com os nossos, quando assinala que "O xamanismo é uma importante instituição nas sociedades nativas da América do Sul [...] Seu objetivo principal é descobrir e lidar com as energias que existem por detrás dos eventos cotidianos [...] O xamã interage com essas energias por meio da expêriencia estática, através dos sonhos, ou dos transes induzidos por substâncias ou outras técnicas, servindo como mediador entre os domínios humano e extra-humano. As fontes do poder do xamã são as fontes da própria cultura [...]".

${ }^{13}$ Os autores dedicam grande parte do ensaio central de Current Anthropology a contradizer as diversas interpretações feitas por Peter Furst (1996) sobre representações pré-hispânicas, como imagens de transformações de homens em animais ou de voos xamânicos. Não somos especialistas em iconografía, razão pela qual não podemos opinar sobre o tema, mas estamos conscientes de que uma única figura costuma ter várias alternativas de interpretação e ninguém pode jurar que a sua seja definitiva, somente a mais provável. Outros autores, inclusive renomados especialistas em etno-história e manuscritos, concordam com a existência de representações de transformações e voos nas tradições locais, tal como assinalamos.

${ }^{14}$ No Ritual dos Bacabs, manuscrito maia colonial datado de 1779, mas seguramente uma cópia de outro mais antigo, datado de ao menos 1567, registram-se as palavras que o sacerdote xamã ah-kino h-men deve dirigir às entidades anímicas do mundo outro para obter a restituição da saúde de seus pacientes. Em muitas ocasiões, dirige-se a elas, questionando sua origem: “[...] Quem é você, procriador? Quem é você, o das trevas? Qual foi a sua árvore? Qual foi a tua linhagem? [...]". Também pode agredi-lo com alusões sexuais explícitas" (P. Díaz Cortés 2004:38-39).

${ }^{15}$ O arqueólogo Nicholas Saunders (2005:21) propõe a existência da noção da identidade espiritual entre homens e jaguares, por esta razão as representações escultóricas de homens-jaguar " [...] São seres sobrenaturais, produto da união dos governantes olmecas e seres jaguares míticos [...] A relação simbólica entre os poderosos felinos e os governantes e deuses da sociedade olmeca parece ter sido o início de uma tradição muito persistente no México [...]".

${ }^{16}$ Em um excelente ensaio sobre o tema, Federico Navarrete (2000:165) chega a conclusões similares às nossas, assinalando que "[...] O nagualismo pode ser compreendido como uma técnica de mediação e comunicação entre os planos cósmicos [...] ao permitir que um ser se transforme em outro ser de natureza diferente, ou pertencente a um nível cósmico distinto, abrindo um canal de comunicação e ação que excede o âmbito de ação 'normal' deste ser e lhe permite atuar em outros planos cósmicos [...]". 


\section{Referências bibliográficas}

ABBAGNANO, Nicola. 1963. Diccionario de filosofía. México: Fondo de Cultura Económica.

ARAMONI, Maria Elena. 1990. Talokan tata, talokan nana: nuestras raíces. Colección Regiones. México: Consejo Nacional para la Cultura y las Artes.

AUGSBURGER, Deborah. 2003. "Traduciendo la brujería. 'Brujos, hechiceros y hechizería' en el vocabulario de Córdoba". In: M. A. Romero Frizzi (coord.), Escritura zapoteca. México: CONACULTA-INAH-CIESAS.

BARABAS, Alicia. 1989. Utopías indias. Movimientos sociorreligiosos en México. México: Ed. Grijalbo.

BARTOLOME, Miguel. 1988. La dinámica social de los Mayas de Yucatán. México: CNCA-INI. 1991 [1977]. Chamanismo y religión entre los Avá-Katu-Ete. Asunción, Paraguay: Universidad Católica. - 1997. Gente de costumbre y gente de razón. Las identidades étnicas en México. México: Siglo XXI-INI. 2000. El encuentro de la gente y los insensatos: la sedentarización de los cazadores ayoreo en el Paraguay. México-Paraguay: Instituto Indigenista Interamericano. 2009. Parientes de la selva. Los Guaraníes Mbya de la Argentina. Paraguay: CEADUC-Biblioteca Paraguaya de Antropología.

BARTOLOMÉ, Miguel \& BARABAS, Alicia. 1981 [1977]. La resistencia maya, relaciones interétnicas en el oriente de la península de Yucatán. México: INAH. 2a ed.

; HERNÁNDEZ, Pedro \& MORALES, Bartola. 1999. "Gente de una misma palabra. El grupo etnolinguístico- chinanteco". In: A. Barabas; M. Bartolomé (orgs.), Configuraciones étnicas en Oaxaca, vol. II. México: INAH-INI. BASTIDE, Roger. 2001 [1972]. El sueño, el trance y la locura. Buenos Aires, Argentina: Amorrortu.

BENSON, Elisabeth (coord.). 1972. The cult of the feline: a conference in PreColumbian iconography. Dumbarton Oaks, USA: Harvard University.

BRUCE, Robert. 1975. Lacandon dream symbolism: dream symbolism and interpretation. Vol 1. México: Ediciones Euroamericanas.

. 1979. Lacandon dream symbolism: dictionary, index and classification of dream symbols.Vol. 2. México: Ediciones Euroamericanas.

BURGOA, Fray Francisco. 1989 [1674]. Geográfica descripción. Vol. 2. México: Porrúa.

CASTILlO, María del Carmen. 2010 "Complementaridad simbólica en la cosmovisión ayuujk". In: A. Barabas; M. Bartolomé (coord.), Dinámicas culturales. Religiones y migración en Oaxaca. Oaxaca: Gob. Del Edo. De Oaxaca-INAH.

COE, Michael D. 1965. The jaguar's children: pre-clasic central Mexico. New York: The Museum of Primitive Art.

DE LA GARZA, Mercedes. 1990. Sueño y alucinación en el mundo náhuatl y maya. Instituto de Investigaciones Filológicas. México: UNAM.

DEAN, Colin. 1996. The Australian Aboriginal "dreamtime": its history, cosmogénesis, cosmology and ontology. Victoria, Austrália: Gamahucher Press.

DESCOLA, Philippe. 1989. "Head shrinkers versus shrinks: Jivaroan dream analysis". Man, 24(3):439-450. 
DIAZ-CORTEZ, Patricia Martel. 2004. "La magia de la palabra en el Ritual de los Bacabs", Arqueología Mexicana, XII(69).

DURAN, Fray Diego. 1984. Historia de las Indias de Nueva España e Islas de Tierra Firme. Vol 2. México: Editorial Porrúa.

DURKHEIM, Emile. 1968 [1912]. Las formas elementales de la vida religiosa: el sistema totémico en Australia. Buenos Aires, Argentina: Ed. Schapire.

ELIADE, Mircea. 1960. El chamanismo y las técnicas del éxtasis. México: F.C.E. (1 $1^{\mathrm{a}}$ ed. em francês 1951).

FAGETTI, Antonella (coord.). 2010. Iniciaciones, trances, sueños: investigaciones sobre el chamanismo en México. México: BUAP-Plaza y Valdéz.

. 1973. "Dreams, character and cognitive orientation in Tzintzuntzan". Ethos, 1:106-121.

FOSTER, George. 1973. "Dreams, character and cognitive orientation in Tzintzuntzan". Ethos, 1(1):106-121.

FREIDEL, David; SCHELE, Linda \& PARKER, Joy. 1999. El cosmos maya: tres mil años por la senda de los chamanes. México: Fondo de Cultura Económica.

FURST, Peter. 1980 [1976]. Alucinógenos y cultura. México: Colección Popular, FCE. . 1968. "The Olmec were jaguar motif in the light of ethnographic reality". In: Dumbarton Oaks Conference on the Olmec. Washington, USA: E. Benson. 1996. "Shamanism, transformation, and Olmec art". In: M. Coe et. al. (coord.), The Olmec world: ritual and rulership. Princeton: The Art $\mathrm{Mu}$ seum/ Princeton University.

GALINIER, Jaques. 2009. "La huella cósmica de los sueños en el México indio. Una hipótesis otomí". In: El espejo otomí: de la etnografía a la antropología psicoanalítica. Colección Etnografía de los Pueblos Indígenas de México. México: INAH-CDI-CEMC.
; PERRIN, Michel. 1995. "Introducción". In: I. Lagarriga, J. Galinier, M. Perrin (coord.), Chamanismo en Latinoamérica. México: Ed. Plaza y Valdez Editores-Universidad Iberoamericana.

GLOCKNER, Julio. 1997. "Los sueños del tiempero". In: B. Albores; J. Broda (coord.), Graniceros: cosmovisión y meteorología indígenas en Mesoamérica. México: El Colegio Mexiquense-UNAM. . 2004. "Chamanismo en los volcanes". Arqueología Mexicana, XII(69).

HAMAYON, Roberte. 1990. La chasse à l'âme. Esquisse d'une théorie du chamanisme sibérien. Paris: Société d'ethnologie. 1993. "Are 'trance', 'ectasy' and similar concepts appropriate in the study of shamanism". Shaman, I(2).

HOUSTON, Stephen \& STUART, David. 1989. The way glyph: evidence for co-essences among the classic Maya. Research Reports on Ancient Maya Writing $\mathrm{n}^{\circ}$ 30. Washington: Center for Maya Research.

HUBER, Brad \& SANDSTROM, Alan (coord.). 2001. Mesoamerican healers. USA: University of Texas Press.

JANSEN, Maarten \& PEREZ JIMENEZ, Gabina Aurora. 2008. "Paisajes sagrados: códices y arqueología de NuuDzaui". Revista Itinerarios, 8.

KLEIN, Cecelia; GUZMAN, Eulogio; MANDEL, Elisa \& STANFIELD-MAZZI, Maya. 2002. "The role of shamanism in mesoamerican art: a reassessment". Current Anthropology, 43(3): 382-419.

LAGARRIGA, Isabel; GALINIER, Jaques \& PERRIN, Michel (coord.). 1995. Chamanismo en Latinoamérica. México: Plaza y Valdez Editores.

LANGDON, Jean (org.). 1996. Xamanismo no Brasil. Novas perspectivas. Florianópolis: Ed. Universidade Federal de Santa Catarina. 
LAPLANTINE, Francois. 1977. Mesianismo, posesión y utopía: las tres voces de la imaginación colectiva. Barcelona: Ed. Gedisa.

LAUGHLIN, Robert. 1976. Of wonders wild and new: dreams of Zinacantan. Washington: Smithsonism Institution.

LÉVY-BRUHL, Lucién. 1972 [1922]. La mentalidad primitiva. Buenos Aires: Ed. La Pléyade. 1974 [1927]. El alma primitiva. Barcelona: Ed. Península.

LÉVI-STRAUSS, Claude. 1964 [1962]. El pensamiento salvaje. México: Breviarios/ FCE.

_ 1968 [1949]. "La eficacia simbólica". In: Antropología estructural. Buenos Aires: EUDEBA. - 1986 [1985]. La alfarera celosa. Barcelona: Ed. Paidos.

LOPEZ AUSTIN, Alfredo. 1969. Augurios y abusiones. Textos de los informantes de Sahagún. México: Instituto de Investigaciones Históricas, UNAM. . 1989 [1972]. Hombre Dios: religión y política en el mundo nahuatl. México: UNAM.

_ 1990. Los mitos del tlacuache. México: Alianza Editorial. . 1994. Tamoanchan y Tlalocan. México: F.C.E.

MARCUS, Joyce. 2002. "Invited comment". In: C. Klein et al. "The role of shamanism in Mesoamerican art: reassessment". Current Anthropology, 43(3): 382-419.

MARION, Marie-Odile. 1996. "La oniroromancia maya: un recurso ante el infortunio". Anuario 1996. Chiapas: UCAECH.

MARTÍNEZ GONZÁLEZ, Roberto. 2009. "Sobre la existencia de un nahualismo purépecha y la continuidad cultural en Mesoamérica". Relaciones, 117 (XXX).

MAUSS, Marcel. 1971. Obras completas. Tres Tomos. Barcelona: Barral Ed.
MERRILL, William. 1987. "The rarámuri stereotype of dreams". In: Bárbara Tedlock (ed.), Dreaming. Cambridge: Cambridge University Press.

NASH, Manning. 1961. "Wichcraft as social procesn in a tzeltal community". América Indígena, 20.

NAVARRETE, Federico. 2000. "Nahualismo y poder: un viejo binomio mesoamericano". In: F. Navarrete y G. Olivier (coords.), El héroe entre el mito y la historia. México: UNAM.

NIÑO VARGAS, Juan Camilo. 2007. "Sueño, realidad y conocimiento: noción del sueño y fenomenología del soñar entre los Ette del norte de Colombia". Antípoda, 5.

OROBITG CANAL, Gemma. 2004. "Los sueños como fuentes antropológicas para el estudio de las sociedades amerindias". Primer Congreso Internacional Catalunya-América. Barcelona: ICCC. PERRIN, Michel. 1995. "Lógica chamánica". In: I. Lagarriga, J. Galinier, M. Perrin (coord.), Chamanismo en Latinoamérica. México: Ed. Plaza y Valdez Editores-Universidad Iberoamericana.

PITARCH, Pedro. 1996. "La alteridad íntima como diferencia étnica", "Narrativa, ritual, silencio". In:Una etnografía de las almas tzeltales. México: Fondo de Cultura Económica. pp. 107-198.

REICHEL-DOLMATOFF, Gerardo. 1978. El chamán y el jaguar. México: Siglo XXI Eds.

REYES GOMEZ, Laureano. 2008. "La visión zoque del inframundo". Revista Española de Antropología Americana, 38(2).

ROMERO LÓPEZ, Laura (coord.). 2011. Chamanismo y curanderismo: nuevas perspectivas. México: Benemérita Universidad Autónoma de Puebla. ROULLET, Juliette. 2003. "Espacio ordenado, espacio dilatado: metamorfosis del día a la noche". In: A. Breton, 
A. Monod, M. H. Ruz (coord.), Espacios mayas. Usos, representaciones, creencias. México: UNAM/Centro Francés Estudios Mexicanos y Centroamericanos.

SAHAGUN, Fray Bernardino. 1977 (circa 1547-1580). Historia general de las cosas de la Nueva España. Editada por Ángel María Garibay. 4 Tomos. México: Ed. Porrúa.

SAUNDERS, Nicholas. 2005. "El ícono felino en México". Arqueología Mexicana, XII(72).

SEAMAN, Gary \& DAY, Jane (coord.). 1994. Ancient traditions: shamanism in Central Asia and the Americas. USA: University Press of Colorado/ Denver Museum.

SCHOBINGER, Juan (comp.). 1997. Shamanismo sudamericano. Buenos Aires: Ed. Continente.

SMITH, Thomas. 2001. "Dioses sacerdotes y sacrificios". In: V. de la Cruz, M. Winter (coords.), La religión de los Vinnigula'sa'. México: IEPO-Instituto Oaxaqueño de las Culturas.

SPENCER, Baldwin \& GILLEN, Francis. 1899. Native tribes of Central Australia. Londres: Elibron Classics.

TRANFO, Luigi. 1979. "Tono y nagual". In: Italo Signorini (coord.), Los Huaves de San Mateo del Mar. México: Oaxaca INI, Colección Presencias.

TEDLOCK, Barbara. 1987. Dreaming: anthropological and psychological interpretations. Cambridge: Cambridge University Press.

- 1991. "The new anthropology of dreaming". Dreaming, 1(2). Disponível em: http://www.asdreams.org/journal/articles/1-2tedlock1991.htm

TYLOR, Edward B. 1981 [1871]. Primitive culture. Londres: John Murray.

VALLEJO, Alberto. 2005. "RilajMaam como nawal", "El dios anciano en la tradición religiosa mesoamericana:
RilajMaam, como sostén del mundo". In: Por los caminos de los antiguos nawales (RilajMaam y nawalismo maya tz'utujil en Santiago Atitlán). Obra Diversa. México: INAH. pp.169-213.

VIVEIROS DE CASTRO, Eduardo. 2002. A inconstância da alma selvagem. São Paulo: Cosac \& Naify. 
Resumo

Com base em uma pesquisa etnográfica realizada em todo o México e coordenada pelos autores, da qual participaram mais de 100 antropólogos, este ensaio reflete sobre as concepções e as práticas xamânicas contemporâneas das populações indígenas. Argumenta-se sobre a profundidade histórica de tal instituição na Mesoamérica, rastreável durante diferentes períodos, propondo-se que, embora com importantes transformações, ela mantém evidentes parentescos com a compreensão e a praxis dos atuais especialistas rituais. Uma das conclusões da pesquisa etnográfica sobre a qual nos debruçamos especificamente é a relevância do sonho, a viagem onírica, na configuração social atual da prática xamânica e de seus diferentes campos de ação.

Palavras-chave Xamanismo, Povos Indígenas, Mesoamérica, México atual, Viagem onírica.

\section{Abstract}

Based on an ethnographic research conducted throughout Mexico in which more than one hundred anthropologists participated, guided by the authors, this essay ponders the conceptions and contemporary shamanic practices of indigenous peoples. We discuss the historical depth of the shamanic institution in Mesoamerica. We can follow through different periods suggesting that, although there are important changes, it maintains a close kinship with the understandings and practices of ritual specialists today. One of the main findings of this research is the relevance of dreams and dream journeys in the shamanic practices and in their different fields of action.

Key words Shamanism, Indigenous people, Meso-America, Contemporary Mexico, Dream journeys. 